\title{
Internet of things and machine parts laboratory
}

\author{
Dan Ioan Țarcă ${ }^{*}$, Radu Cătălin T,arcă², and Ioan Constantin T,arcă $\breve{3}^{3}$ \\ ${ }^{1}$ Țarcă Dan Ioan, PFA, Oradea, Romania \\ ${ }^{2}$ University of Oradea, Mechatronics Department, Oradea, Romania \\ ${ }^{3}$ University of Oradea, Mechanical Engineering and Automotive Department, Oradea, Romania
}

\begin{abstract}
Internet of Things (IoT) is a relatively new approach. Due to its wide spreading and simplicity it has a various number of application, practically in every domain. This paper aims to present the way in which a classic stand can be transformed into a microprocessor-controlled system. The chosen stand is related to experimental determination of the friction coefficient and efficiency for a threaded mechanism.
\end{abstract}

\section{Theoretical considerations}

Same as threaded joints, in threaded mechanisms the friction torque between threads in nut and bolt is proportional to axial load, thread diameter and helix angle, number of threads and friction coefficient between threads. The relationship between axial load and friction torque is presented in eq. 1 .

$$
M_{f 1}=\frac{1}{2} F \cdot d_{2} \cdot \tan \left(\beta_{2}+\varphi^{\prime}\right)
$$

Where

$M_{f 1}$ is the friction torque

$F$ is the axial load

$d_{2}$ is the mean diameter of the thread

$\beta_{2}$ is the helix angle of the thread measured on the mean diameter (eq.2)

$$
\beta_{2}=\operatorname{arctg} \frac{p}{\pi \cdot d_{2}}
$$

$p$ is the thread pitch

$\varphi$ ' is the reduced friction coefficient (eq.3)

$$
\tan \varphi^{\prime}=\mu^{\prime}=\frac{\mu}{\cos \frac{\alpha}{2}}
$$

$\mu$ is the friction coefficient for the bolt and nut materials

$\alpha$ is the angle of the thread profile.

In Mechanical Engineering student laboratory activities this torque is measured by the mean of an elastic system based on a spring and a device used to measure the elongation of the spring, for example a dial indicator. In this paper the authors present a way to develop this stand using affordable components with small modification in the mechanic system of the stand.

\section{Stand analyses}

\subsection{Existing test stand [1]}

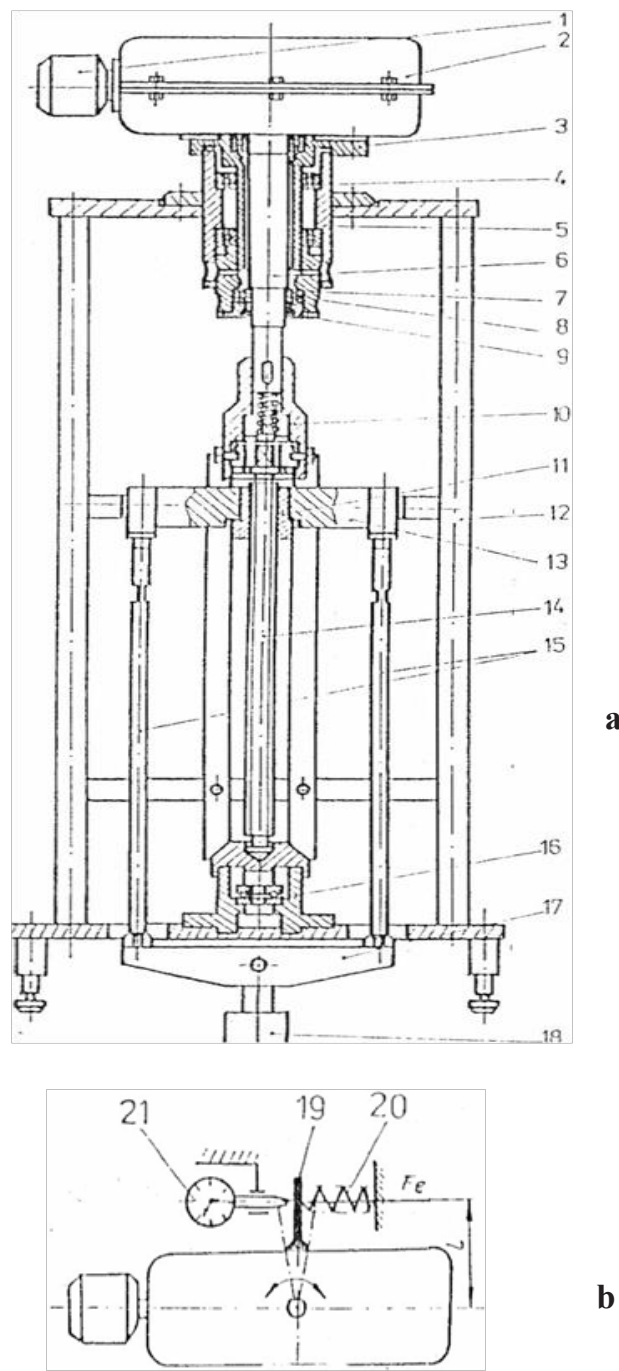

Fig.1 Stand for studying the friction torque in threaded mechanisms. a. the complete stand; b. the measurement system

\footnotetext{
* Corresponding author: bh90tdi@gmail.com
} 
The original test stand is presented in fig. 1 and is composed by DC motor (1) which rotates the threaded bolt (14) by the mean of a worm gear mounted inside a housing (2), a shaft (6) and a clutch (10).

The radial bearing (5) ensures that the shaft is correctly positioned against the fixed crosspiece of the device during operation.

The threaded bolt rotation generates a translational movement of the nut (11) and also of the crosspiece (13) which is guided by the columns (12). Axial load is created through the weights (18) attached to the crosspiece (17) which load the nut through tyrants (15).

During the lifting of the weights (18) axial load creates a frictional torque between the bolt threads and nut threads which acts as a resistance in the rotating movement of the bolt. Currently the fictional torque is measured by the mean of an elastic system which uses a spring (20) and a dial indicator (21) which measures the displacement of the indicator (19). The spring and the dial indicator are placed at the certain distance (L) from the rotational axis. When the friction torque equals the torque generated by elastic forces the system is in equilibrium. In this case one can calculate the value of the torque generated by the elastic force:

$$
M_{t}=F_{e} \cdot L=k x L
$$

Where:

$M_{t}$ is the torque generated by the elastic forces (spring)

$F_{e}$ is the elastic force developed in spring; $F_{e}=k x$

$k$ is the characteristic of the spring

$x$ is the spring deformation, measured by the dal indicator

$L$ is the distance between the dial indicator and bolt axis

Tests are made for different weights.

\subsection{Modernized test stand}

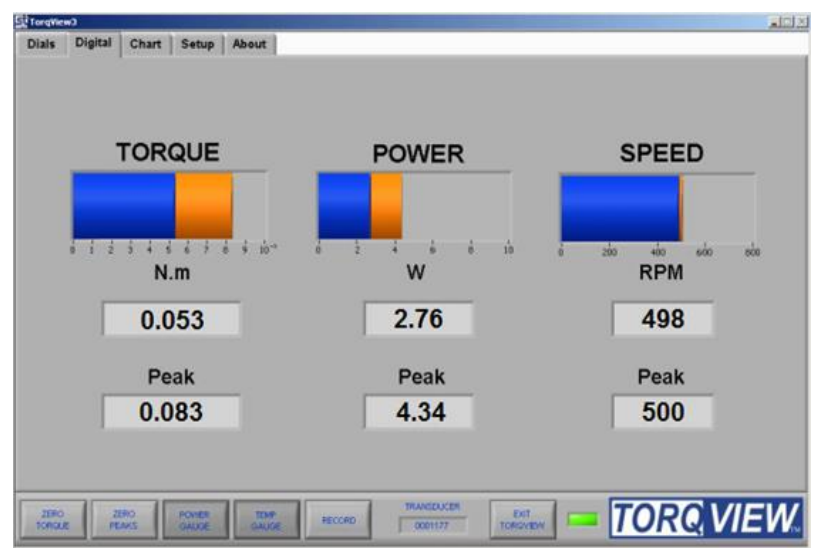

Fig. 2 Interface for data acquisition of torque

Another way of measuring the resistant torque is by the main of a torque sensor which will transmit to a PC both the values of the measured torque and the motor speed. Also, power absorbed by the motor can be measured. The interface for data acquisition is presented in fig. 2 together with the results measured by the sensor. For this case an expensive E200 ORT optical torque sensor from Sensor Technology is used, on a scale of 1 $\mathrm{Nm}$, placed between the shaft and the threaded bolt. From the original stand measuring elements 19 to 21 are no longer needed.

\subsection{Internet of Things modified stand}

A simpler and cheaper way for measuring the resistant torque is presented in fig.3. The measurement principle is similar to the first stand i.e. torque is calculated by the mean of applied forces. A load cell sensor (20) mounted in a fixture (21) is used as a force sensor, without the need of a spring. The sensor is pushed with the force $F_{e}$ by an arm (19) provided with a tip placed at a distance L from the centre of rotation of the threaded bolt which generates the force to be measured. Usually a load cell sensor is used in equipment to gauge weight and force. In this case the friction forces generated by the rotation of the bolt are measured by the mean of the cell sensor. The sensor unit voltage signal is converted into a digital signal using a 24bit analogue-digital converter (ADC) and transferred to a microcontroller unit (MCU). The force logger schematic is presented in fig.4. The supply voltage values are indicated by $(\mathrm{E}+)$ and (E-) while load cell output voltage is indicated by ( $\mathrm{S}+$ ) and ( $\mathrm{S}-)$. In fact, the load cell sensor is a classic Wheatstone bridge following the classic rules presented in equation 5 .

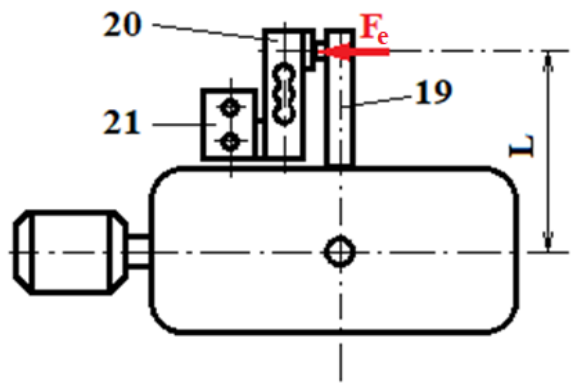

Fig. 3 Stand modified for load cell sensor

$$
\begin{gathered}
V_{R 2}=I_{U} \cdot R_{2}=\frac{V_{\text {ref }}}{R 2+R 1} R 2 ; V_{R 4}=I_{B} \cdot R_{4}=\frac{V_{\text {ref }}}{R 3+R 4} R 4 \\
V_{\text {OUT }}=V_{R 2}-V_{R 4}=\frac{R 2 R 3-R 1 R 4}{(R 2+R 1)(R 3+R 4)} V_{\text {ref }}
\end{gathered}
$$

Where:

$\mathrm{V}_{\mathrm{R} 2}$ and VR4 are the voltage across $\mathrm{R} 2$ and $\mathrm{R} 4$ respectively (fig.4)

$R_{1}$ and $R_{2}$ respectively $R_{3}$ and $R 4$ are the left and right branches of the Wheatstone bridge

$I_{V}$ and $I_{B}$ are currents passing on the left and respectively right branches.

$\mathrm{V}_{\text {OUT }}$ is the output voltage of the Wheatstone bridge

$\mathrm{V}_{\text {ref }}$ is the excitation (or supply) voltage

For this stand a $5 \mathrm{~V}$ power supply is set as the reference or excitation voltage $\left(\mathrm{V}_{\text {ref }}\right)$. Descriptions of the load cell sensor is presented in table 1 .

Maximum output force measured on the first presented stand, achieved for a loading weight of $6.95 \mathrm{~kg}$ $(79.99 \mathrm{~N})$ was $1.359 \mathrm{~N}$, so that a maximum output of $3 \mathrm{~N}$ which can be measured by the load cell sensor is more 
than sufficient to achieve usual laboratory values, which are shown in table 2 .

Table 1 Load sensor cell properties

\begin{tabular}{|c|c|}
\hline Rated output & $1.0 \pm 10 \% \mathrm{mV} / \mathrm{V}$ \\
\hline Excitation & $3-15 \mathrm{~V}$ \\
\hline Zero balance & $\pm 5 \% \mathrm{RD}$ \\
\hline Nonlinearity & $\pm 0.02 \% \mathrm{RD}$ \\
\hline Hysteresis & $\pm 0.015 \% \mathrm{RD}$ \\
\hline Repeatability & $\pm 0.015 \% \mathrm{RD}$ \\
\hline Creep(30min) & $\pm 0.03 \% \mathrm{RD}$ \\
\hline Safe overload & $150 \%$ F.S. \\
\hline Ultimate overload & $200 \%$ F.S. \\
\hline $\begin{array}{l}\text { Compensated } \\
\text { temperature }\end{array}$ & $-10 \ldots+40^{\circ} \mathrm{C}$ \\
\hline $\begin{array}{l}\text { Operating } \\
\text { temperature }\end{array}$ & $-20 \ldots+60^{\circ} \mathrm{C}$ \\
\hline $\begin{array}{l}\text { Temperature shift } \\
\text { zero }\end{array}$ & $\pm 0.05 \% \mathrm{RD} / 10^{\circ} \mathrm{C}$ \\
\hline $\begin{array}{l}\text { Temperature shift } \\
\text { span }\end{array}$ & $\pm 0.03 \% \mathrm{RD} / 10^{\circ} \mathrm{C}$ \\
\hline Input resistance & $405 \pm 10 \mathrm{ohms}$ \\
\hline Output resistance & $350 \pm 3$ ohms \\
\hline $\begin{array}{l}\text { Insulation } \\
\text { resistance }\end{array}$ & $>2000 \mathrm{M} \mathrm{ohms}$ \\
\hline Ingress protection & IP65 \\
\hline Material of element & Aluminium alloy \\
\hline Cable & $\varnothing 4 * 250 \mathrm{~mm}$ \\
\hline Wiring code & Red--E+ Black--E- Green--S+ White--S- \\
\hline
\end{tabular}

Table 2 Data achieved during tests for classic stand

\begin{tabular}{|l|c|l|l|l|}
\hline \multicolumn{1}{|c|}{ Specification } & U/M & Value 1 & Value 2 & Value 3 \\
\hline Bolt /nut materials & - & \multicolumn{3}{c|}{ Steel/Bronze } \\
\hline Thread type & - & \multicolumn{3}{c|}{ Tr24 } \\
\hline Load & $\mathrm{N}$ & 56.408 & 65.727 & 77.990 \\
\hline Load & $\mathrm{kg}$ & 4.75 & 5.70 & 6.95 \\
\hline Spring elongation & $\mathrm{mm}$ & 1.75 & 2.05 & 2.47 \\
\hline Friction torque & $\mathrm{N} \cdot \mathrm{mm}$ & 96.250 & 112.750 & 135.850 \\
\hline Force in spring & $\mathrm{N}$ & 0.963 & 1.128 & 1.359 \\
\hline Friction coefficient & - & 0.080 & 0.081 & 0.084 \\
\hline Efficiency & - & $46.64 \%$ & $46.39 \%$ & $45.68 \%$ \\
\hline $\begin{array}{l}\text { Distance from } \\
\text { measurement system to } \\
\text { axes }\end{array}$ & $\mathrm{mm}$ & & 100 \\
\hline
\end{tabular}

The force logger scheme is presented in fig.4, while in fig. 5 the wiring scheme can be seen. The voltage for the load cell is supplied by the 24bit HX711 ADC and amplifier, and input values of the voltage difference are also acquired and amplified by the HX711 module (fig.4), then transmitted to the Arduino Uno microcontroller system which converts data into useful information on a display. With a rated output of $1 \mathrm{mV} / \mathrm{V}$, for an excitation voltage of $5 \mathrm{~V}$ the load cell will produce at maximum load (full scale, which corresponds to $0.3 \mathrm{~kg} \mathrm{x}$ $\left.9.81 \mathrm{~m} / \mathrm{s}^{2}=2.943 \mathrm{~N}\right), 5 \mathrm{mV}$.

The resolution of the scale is given by the $\mathrm{AD}$ converter, that is:

$$
\text { Resolution }=\frac{5 \mathrm{~V}}{2^{24}}=0.298 \mu \mathrm{V}
$$

This specification is not usable, since the noise generated by wire and the environment have greater values.

The sensitivity of the load cell is calculated based on relation [2]:

Sensitivity $\left[\frac{\mathrm{mV}}{\mathrm{N}}\right]=\frac{\text { exc voltage }(\mathrm{V}) \times \text { rated output }\left[\frac{\mathrm{mV}}{\mathrm{V}}\right]}{\max \text { force }[\mathrm{N}]}$

With actual values sensitivity is $1.698 \mathrm{mV} / \mathrm{N}$, which is quite satisfying.

Conversion of the output value of the load cell to force values is based on the formula [3]:

Force $[N]=K \times\left(\right.$ Rated output $\left[\frac{\mathrm{mV}}{\mathrm{V}}\right]-$ offset $)$

Calibration of the load cell is made in two steps. Firstly, the offset of the load cell is measured, by putting the load cell on a plane surface, unloaded, while measuring the output value.

$K$ factor (load cell factor) is computed by comparison to known forces applied to the cell while adjusting the output to correct value. After knowing the $K$ value, equation 8 can be used to compute the force measured by the load cell.

If needed, the value of the friction torque can be directly displayed by multiplying relation 6 with the distance from the threaded bolt to the point where the force is applied. The $16 \times 2 \mathrm{I}^{2} \mathrm{C}$ (Inter-integrated Circuit) liquid crystal display (LCD) outputs the values of the force (torque) on the first row and eventually, the value of threaded bolt rotational speed, if needed.

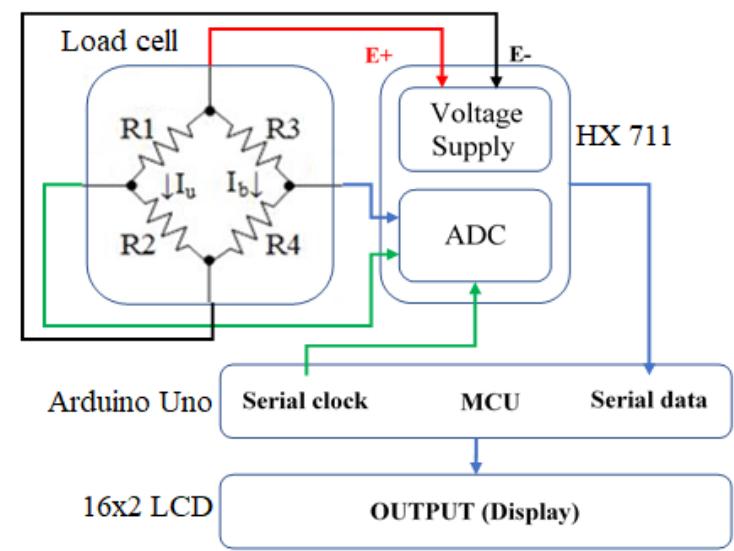

Fig. 4 Force logger principle 


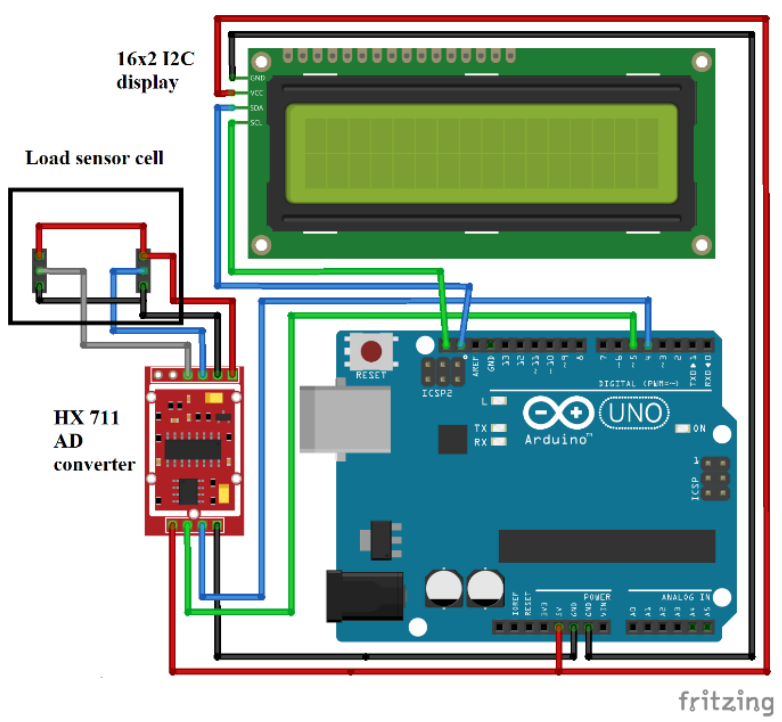

Fig. 5 Wired scheme of the force logger

As Microcontroller Unit (MCU), the Arduino UNO capabilities are exploited, due to its affordability, ease of use and simplicity in writing code [4]. Also, Arduino Nano is suitable for this modification, if miniaturization is one of the desired aspects of the designer.

Other modules can be attached to the Arduino, such as analogue inputs for continuous data reading, digital ports either for input (used with digital sensors) or output (for example modification of the motor speed using power width modulation (PWM) facilities of the board) and so on.

\section{Conclusions}

Laboratory activities for mechanical engineering students might be at a crucial point. Due to rapid development of Mechatronics and their spread in all field of activity, Internet of Things emerges, giving a new breath to classic assumption of mechanical engineering.

Many of the stands based of force measurements can be adapted as presented in the paper, with almost no effort, both financial and material.

Three types of stands were presented in the paper:

The classic mechanical stand, which uses the deformation of an elastic system deformation (spring) to measure forces and thus, torques, and all other physical dimensions. Even though is an obsolete method, it has the advantage of making students to find all kind of means (direct or indirect) by which one can measure needed dimensions.
The second method allows, with small changes in the configuration of the stand, to get more accurate results, near to those acquired in specialized laboratories, which, for research purposes is mandatory. For didactic activities though, these professional or semi-professional systems are too expensive for their purpose, which mainly is to offer students ways to find correlations between certain physical/mechanical dimensions.

Finally, the last method uses common, low priced materials. Not only that the new concept of Internet of Things offers a large variety of solutions to daily problems, but, as a matter of fact, this concept allows the students to easily access the world of experiment and innovation.

In this paper, the modification made to the laboratory consisted in changing the obsolete mechanical way of measuring with a combined one, in which microcontrollers together with microelectromechanical systems (MEMS) play an important role. The elastic system (spring) has been substituted with another elastic system (load cell), but sensors (resistive gauges) took the place of the dial indicator. Other problems related to the design of the IoT system were the selection process of the load cell, the problems related to transducers selection, creating the software for measurement and also for the control of the system, and so on.

Also, differences between the second method presented in the paper and the IoT one resides in the fact that beside the fact that IoT is much cheaper, it sustains the students' creativity, motivating them to find functional solutions with a great level of confidence in respect to the results.

\section{References}

1. C. Cornea, Machine Parts. Laboratory Handbook (Organe de Masini. Indrumar pentru lucrări de laborator), (1996)

2. W. K. Lee, et al. Physiological Signal Monitoring Bed for Infants Based on Load-Cell Sensors. Sensor Journal, 390-409, (2016).

3. https://www.phidgets.com/docs/Load_Cell_Primer

4. A.G. Smith, Introduction to Arduino: A piece of cake!, www.introtoarduino.com (2011)

5. M.R. Thakur, Measurement made simple with Arduino,

https://docs.google.com/viewer? $\mathrm{a}=\mathrm{v} \& \mathrm{pid}=$ sites\&srci d=ZGVmYXVsdGRvbWFpbnxwYXRyaWNpYXN 1c2FuYW5pbmRpdGF8Z3g6NTE5NjU2MTR1ZjM 0ODA1Zg (2016) 